Микола ЮДОВ,

Катерина ПИВОВАРОВА

\title{
ПРОБЛЕМИ ІНКЛЮЗИВНОЇ ОСВІТИ У ПРОЦЕСІ ПІДГОТОВКИ АКТОРІВ ДРАМАТИЧНОГО ТЕАТРУ В УМОВАХ ВИЩОЇ ШКОЛИ
}

У статті вивчається питання дочільності надання особам з особливими потребами, зокрема із синдромом Дауна, вищої освіти за спечіальністю «Актор драматичного театру» та досліджується досвід такої фахової підготовки в Україні на прикладі Київського начіонального університету культури і мистецтв. Наукова новизна поставленої проблеми полягає у тому, щзо вперше зроблена спроба висвітлення проблем запровадження інклюзивної мистецької освіти в Україні.

Ключові слова: інклюзивна мистецька освіта, вища школа, актор драматичного театру, синдром Дауна.

В статье изучается вопрос иелесообразности получения лицам с особыми потребностями, в частности с синдромом Дауна, высшего образования по специальности «Актер драматического театра» и исследуется опыт такой профессиональной подготовки в Украине на примере Киевского национального университета культуры и искусств. Научная новизна поставленной проблемы заключается в том, что впервые предпринта попытка освещения проблем внедрения инклюзивного художественного образования в Украине.

Ключевые слова: инклюзивное художественное образование, высшая школа, актер драматического театра, синдром Дауна.

Problems of inclusive education in the process of training drama theater actors in condition of higher school.

The article examines the issue of necessity of providing students with special needs, in particular with the Down syndrome, a higher education in the specialty "Actor of the Drama Theater". Also, the article examines the experience of this kond of professional training in Ukraine on the example of the Kiev National University of Culture and Arts. The scientific novelty of the problem posed is that it's the first attempt of highlighting the problems of the introduction of inclusive artistic education in Ukraine.

Key words: inclusive artistic education, high school, drama theater actor, Down syndrome.

За даними Міністерства соціальної політики у 2018 році у порівнянні з 1990-м вдвічі збільшилась кількість людей з інвалідністю. Якщо у 1990 році кількість людей з особливими потребами складала $3 \%$ населення, то сьогодні в Україні ця цифра сягає $6 \%$ (близько 3 млн осіб). 3 них понад 165 тисяч діти. Майже $80 \%$ людей з особливими потребами - люди працездатного віку. Сьогодні ставлення суспільства до цієї категорії населення стрімко змінюється, але головною все ж таки залишається проблема рівності всіх у доступі до цивілізаційних благ, починаючи із користування транспортом і закінчуючи освітою та працевлаштуванням.

Мета цієї розвідки - окреслити коло проблем, пов'язаних із навчанням людей з особливими по- требами в умовах вищої школи та проаналізувати досвід їх вирішення на прикладі підготовки фахівців зі спеціальності «Актор драматичного театру».

27 травня 2017 прийнято Закон України «Про внесення змін до Закону України «Про освіту» щодо особливостей доступу осіб з особливими освітніми потребами до освітніх послуг» [6]. 3окрема у Законі «Про освіту», прийнятому 5 вересня 2017 року [7] з'явилась нова стаття — «Стаття $23^{1}$. Забезпечення реалізації права на освіту осіб з особливими освітніми потребами», якою визначено сутнісне розуміння термінів: «особа з особливими освітніми потребами - це особа, яка потребує додаткової постійної чи тимчасової підтримки в освітньому процесі з метою забезпечення права 
на освіту, сприяння розвитку особистості, поліпшення стану здоров'я та якості життя, підвищення рівня участі у житті громади». Також новим документом, закріплюючи право на освіту для осіб 3 особливими освітніми потребами, за державою визначається обов' язок надавати таким особам рівну можливість здобувати освіту в усіх навчальних закладах, у тому числі безоплатно в державних і комунальних навчальних закладах. Система освітніх послуг, що забезпечує реалізацію права на освіту осіб з особливими освітніми потребами, а також їх соціалізацію та інтеграцію в суспільство визначається терміном інклюзивне навчання [6]. У змінах до чинного законодавства передбачається запровадження дистанційної та індивідуальної форм у процесі інклюзивного навчання.

Натомість суть нового документа про запровадження в Україні нових підходів до інклюзивної освіти фактично спрямована на реформування загальноосвітніх навчальних закладів, залишаючи поза увагою систему вищої освіти — «Для здобуття загальної середньої освіти створюються вечірні (змінні) школи, інклюзивні та/або спеціальні класи для навчання осіб з особливими освітніми потребами, а також класи, групи з очною, заочною, дистанційною формами навчання при загальноосвітніх школах» [6]. Такий підхід, безперечно, надає можливість дітям шкільного віку отримувати психолого-педагогічну та корекційно-розвиткову допомогу у загальноосвітніх навчальних закладах.

Від питань законодавчого забезпечення освітньо-реформаторських процесів українське суспільство мало-помалу переходить до практичних дій. Так, наприклад, перша леді України Марина Порошенко в інтерв'ю Еспресо ТВ з нагоди Всесвітнього дня людей із синдромом Дауна, розповіла про пілотний проект запровадження методів інклюзивної освіти у Запорізькій області [8]. Як зрозуміло стає з їі виступу, у в цій царині відбуваються реальні позитивні зрушення.

Але на цьому інформаційному тлі простежується тенденція залишити поза увагою систему інклюзивної вищої освіти, особливе місце в якій посідає мистецька освіта. Звертались до вивчення проблем вищої мистецької освіти у різних площинах, зокрема у театральній, та шукали шляхи підвищення ефективності багато вітчизняних дослідників, таких як Безгін О. [1], Бурлуцький А. [2], Висоцький Ю. [3, 4, 5], Кочарян I. [10, 11, 12, 13], Кирик Д. [9], Максименко Г. [14], Миленька Г. [1], Овчієва Л. [15], Остропольський Л. [16], Петелько С. [17], Підлісна Л. [18] та ін. Але досі залишається нерозв'язаною низка питань щодо фахової театраль- ної інклюзивної освіти, зокрема акторської для осіб із синдромом Дауна.

Першим, наразі, постає питання потреб суспільства у підготовці акторських кадрів нетипової зовнішності. Адже сучасному професіональному акторові, щоб стати затребуваним на ринку праці і конкурентоспроможним на ньому, слід бути якомога універсальним щодо спектра виконуваних ним ролей. То які ж є об'єктивні суспільні та мистецькі передумови необхідності фахової підготовки акторів для осіб з особливими освітніми потребами, зокрема людей із синдромом Дауна?

Безумовним позитивним фактором фахової підготовки акторів із синдромом Дауна $\epsilon$, насамперед, соціалізація цих людей. Потрапляючи у творчий колектив однодумців, на чолі $з$ педагогом, вони мають можливість розкрити свої таланти. Процес навчання стає паралельно і процесом суспільної адаптації. Поступово людина перестає бути тягарем для родини і зрештою для суспільства. Здобувши акторську освіту, актор із синдромом Дауна може працювати в кіно, хоча і рідше, але й у театрі, маючи голос, може співати в хорі, легко і добросовісно справлятись із виконанням обов'язків натурника у художніх майстернях.

Прикладів тому, як люди із синдромом Дауна знайшли себе в акторській професії, достатньо. Стефані Гінз - перша актриса в історії кінематографа із синдромом Дауна - народилася з трьома хромосомами 21-ї пари замість двох. Фільм «Дуо» за її участі, що вийшов у 1996 році, став кінематографічною сенсацією та був відзначений багатьма кінематографічними нагородами: премія Американської кіноакадемії, премія Чиказького міжнародного кінофестивалю, нагорода Wasserman за найкращу кінематографію, нагороди Warner Brothers. Через роки після виходу фільму Стефані захистила ступінь доктора медичних наук в Університеті Волтера Джонсона у Бетесді, штат Меріленд, США. Впродовж навчання у вузі дівчина грала у декількох театральних постановках. Пабло Пінеда - іспанський актор, який отримав у 2009 році нагороду «Срібна мушля» на Міжнародному кінофестивалі у Сан-Себастьяні за кращу чоловічу роль у фільмі «Я теж». Він мешкає в Малазі й працює у муніципалітеті, а також викладає. Пабло має декілька освітніх дипломів: педагога, бакалавра мистецтв і диплом з педагогічної психології. Паула Саж знялась у декількох фільмах, за роль у британській кінострічці «Після життя» вона отримала премію BAFTA (The British Academy of Film and Television Arts) у номінації «Найкращий дебют у кіно», окрім цього, вона професіонально грає у нетбол (різ- 
новид баскетболу для жінок), працює адвокатом. Паскаль Дакьюнн - актор з Бельгії. Він знявся у кінострічці «Восьмий день», за що отримав премію від Каннського кінофестивалю, як найкращий актор. 27-річна Джемі Брюєр у 2011 отримала роль у відомій «Американській історії жахів», якою здобула прихильність глядачів у всьому світі. Також брала участь у серіалі «Саутленд». Кар'єра Люка Зіммермана розпочалась у 1990 році зі зйомок у картині «Донька вулиці», хоча справжню популярність йому принесла роль Тома Боумана у серіалі «Потай від батьків». Також Люк брав участь у декількох епізодах у серіалі «Радість».

Восени 2007 року, в межах акції «Люди як люди, тільки з синдромом Дауна», до Києва приїздив 3 Москви драматичний «Театр Простодушних». У ньому немає акторів у звичному розумінні, весь основний склад - це люди з синдромом Дауна. Існуючи як благодійний творчий проект, театр, однак, у своєму репертуарі має декілька вистав: спектакль-балаган за М. Гоголем «Повість про капітана Копейкіна» (глава 3 поеми «Мертві душі»); спектакль-містерія О. Ремізова «Бісівське дійство над деяким чоловіком, з прологом: суперечка живота зі смертю», вистава-притча «Звір» за мотивами антиутопії М. Гіндіна та В. Синакевича, «Болдінські драми» за О. Пушкіним та ін. [19].

У 2008 році, в Мінську, під егідою громадського об'єднання «Даун Синдром» 3'явився театр «Сонячні діти» — єдиний у Білорусії театр для молоді 3 синдромом Дауна. Колектив часто їздить з гастролями по Білорусі, також вже побував в Україні і Словаччині. «Сонячні діти» улюблені і затребувані публікою. Глядачі приймають їхні виступи з радістю, довго аплодують. За рік театр зазвичай ставить один спектакль і невелику інсценізацію [20].

Історія українського кіномистецтва та театру не може похизуватись такими здобутками акторів, хворих на синдром Дауна. Але завжди слід iз чогось починати. Прикладом того як викладачі Київського національного університету культури і мистецтв (кафедра режисури та майстерності актора) - заслужений діяч мистецтв України, професор П. І. Ільченко та викладач К. В. Пивоварова - ризикнули та прийняли на акторський курс юнака Д. 3 діагнозом синдром Дауна. До навчання студент, маючи вокальні здібності, вже мав досвід роботи у хоровому колективі оперної студії Національної музичної академії України імені П. І. Чайковського, де брав участь у виставі «Царева наречена» М. Римського-Корсакова.

За свідченням викладачів, всі чотири роки навчання студент (Д. поступив відразу на другий курс) послідовно засвоював всі етапи навчальної програми, звітуючи кожного семестру про виконання творчих завдань, виконуючи ролі, старанно підбираючи костюми, грим, реквізит, і зрештою цілком заслужено отримав диплом бакалавра і згодом спеціаліста у 2017 році. Диплом спеціаліста Д. захищав роллю жандарма у комедії М. Старицького «За двома зайцями» - він, зриваючи оплески, у фінальній сцені вистави заарештовував Свирида Голохвастова. Значним здобутком для студента та його викладачів стала на третьому курсі його роль Рудого пса у студентській виставі «Мауглі» за Кіплінгом. Ця вистава стала лауреатом Всеукраїнського фестивалю театрального мистецтва «Мрій-Дім» у Прилуках у 2014 році. Іноді у студентських роботах, з огляду на вокальні дані Д., його використовували як вокаліста. До визначальних рис сценічної манкості Д. можна віднести природність, чарівність. Зі слів П. І. Ільченка, що «Д. дуже добре сприймала публіка. Він виходив на сцену, і завжди відчувалась позитивна енергія. Недаремно таких людей називають “сонячні люди”. Його завжди сприймали з доброю посмішкою».

Оцінюючи пройдений шлях здобуття студентом Д. акторської професії, педагоги засвідчують, що мали певні труднощі. Адже поведінка Д. інколи була не цілком адекватною. А, враховуючи колективний вид творчості у роботі над створенням театральної вистави, навички вербального і невербального спілкування на сцені між акторами та акторами і режисером стають провідною складовою художньо-постановочного процесу. «Театр - це мистецтво спілкування, — каже П. І. Ільченко і у спілкуванні важлива гармонія, контрапункт». Студенту Д. інколи це давалось важко. Але викладачі навчились терпляче приборкувати акторську гіперактивність Д., спрямовуючи ії у правильне русло та стримуючи його емоційні прояви. Д. завжди хотів грати багато і робив це старанно та заповзятливо. Характерною рисою в манері роботи Д. над роллю була педантична, ретельно-точна виконавська слухняність у сценічному втіленні режисерських вказівок з подальшою довготривалою фіксацією у його пам'яті знайдених пластичних рішень. «Якщо йому давати якийсь чіткий візуальний малюнок, то він залізно буде повторювати запропоноване дуже точно: мізансцени, жести, міміку... По формі вони [актори з синдромом Дауна] тримають все дуже чітко. Можна сказати, що “театр удавання” їм ближчий, ніж “театр переживання"»,—- стверджує П. І. Ільченко.

Щодо особливостей методики викладання фахових дисциплін, то набутий викладачами в результаті 
викладання фахової дисципліни «Майстерність актора» свідчить, що слід ширше використовувати індивідуалізований підхід, як, власне, i до будь-яких інших типових студентів творчих спеціальностей. На вступних творчих іспитах викладачам слід зрозуміти ступінь вмотивованості особи і щирості у прагненні до навчання, а також переконатись у відсутності схильності до агресивності у поведінці та здатності йти на контакт з оточенням. Необхідною умовою зарахування на акторський курс також $є$ природна здатність до запам'ятовування інформації. Для цього абітурієнт має продекламувати вірш, байку, монолог, уривок з прози. Перевіряють також і музично-пластичні здібності- виконується танок або ритмічні рухи під музичний супровід. Виконання може видаватися навіть дещо незграбним, смішним та недосконалим, але художньо привабливим, що свідчитиме про наявні творчі здібності.

Також викладачі відзначили, що на перших етапах навчання важливо, щоб педагоги за активної участі батьків дитини з особливими освітніми потребами делікатно і вміло роз'яснили їй, що на курсі ймовірно поруч навчатимуться діти, яких, можливо, будуть більше відзначати, але все одно потрібно наполегливо працювати, щоб у висновку здобути омріяну професію.

Досвід викладачів курсу, де навчався студент Д. із синдромом Дауна, свідчить, що не варто якось особливо вирізняти такого студента, перебільшено поблажливо до нього ставитись. Він має відчувати, що він такий, як усі, можливо, лише за винятком надмірного фізичного навантаження. Тоді й однокурсники ставитимуться до нього як до рівного, приймуть у свій творчий колектив. Врешті-решт це спрацьовуватиме на досягнення загальних результатів у навчанні. Чим вище студент ставитиме собі планку для творчих звершень, тим вищим буде результат. Така формула діє і стосовно студентів із синдромом Дауна. Рівне ставлення до всіх членів колективу проявляється від малого - недопущення до занять в разі запізнення, справедлива оцінка за невиконану чи недовиконану самостійну роботу до більшого, наприклад, до справедливого розподілу ролей. Єдине, що слід завжди пам'ятати викладачевi,-—це те, що неодмінно треба вчасно відзначити, похвалити за докладені зусилля студента. Адже, попри зрілий вік, ці люди по-дитячому сприйнятливі до поведінки оточення й більше за інших дорослих чекають на позитивну оцінку своєї творчості. Вони щиро, по-дитячому радіють, через що отримують натхнення до нових звитяг. Тут варто визнати, що насправді викладачам іноді доводилось дещо знижувати вимоги до творчих результатів студента Д., але не надмірно, в межах індивідуального підходу до оцінки результатів навчання.

Також викладачі своїм прикладом мають навчити весь колектив спокійно ставитись до проявів індивідуальної поведінки колеги із синдромом Дауна. Недарма таких людей називають «сонячні діти» — вони іноді по-дитячому не в такт сміються або посміхаються. Але важливо правильно реагувати на таку поведінку - сміятись, якщо смішно, а не лякатись, та, борони боже, ніколи не насміхатись чи ображати людину. Якщо поведінка потребує корекції, треба пояснювати, робити зауваження, іноді навіть сварити. Тобто реагувати, як на поведінку типового студента. Таке рівне ставлення викладача до всіх членів колективу сприятиме процесу нормальної швидкої адаптації студента з особливими освітніми потребами у студентській спільноті.

Практичний досвід та спостереження викладачів курсу П. І. Ільченка та К. В. Пивоварової свідчать, що студенти із синдромом Дауна легше засвоюють навчальний матеріал в усній формі сприйняття. Хоча інколи для повноцінного засвоєння їм доводиться деякі фрагменти повторювати неодноразово, пояснюючи, що і як треба виконувати. Дещо складнішим для цієї категорії студентів $€$ емоційне сприйняття матеріалу - практичного показу. Щонайменше засвоюється матеріал у пластичній, безсловесній, жестовій, мімічній формі, оскільки людям із синдромом Дауна важко концентрувати увагу.

Осмислюючи пройдений шлях студентом Д. у здобутті акторської професії, можна стверджувати, що це були непрості роки життя, але завдяки цьому він оволодів навичками роботи і спілкування у колективі, зрозумів, що таке нести відповідальність перед колективом за спільну справу, навчився перейматись загальними потребами, радіти і сумувати не лише за себе, а й за інших. Набуваючи творчого досвіду, стаючи професіональним актором, Д. паралельно розвивав особистісні світоглядні горизонти, навчався дисципліні, оволодівав навичками пристосовування до запропонованих життєвих обставин. Він став більш емоційно рухливою, кмітливою, практичнішою, винахідливішою, творчою людиною. Такі позитивні висновки з набутого досвіду.

Але поряд із позитивними враженнями педагоги відчували і певні труднощі, негативні моменти і прояви. Так іноді, власне, лише декілька разів за чотири роки навчання, під час відповідальних заходів, екзаменаційних показів Д. занадто збуджувався і не міг опановувати свої емоції. Тоді викладачам доводилось його додатково пильнувати під час вистави, особливо щодо координації рухів. Зрештою хлопець переважно успішно справлявся зі 
своїми емоціями і працював у межах своїх рольових завдань. Інколи були випадки, коли він міг засперечатися з викладачем, але, вислуховуючи спокійні, переконливі аргументи, зрештою погоджувався і виконував запропоноване викладачем завдання. Також викладачі помічали інколи надмірну допитливість свого студента, яка зникала після зрозумілого, правдивого пояснення,- - Д. погоджувався і більше не перепитував.

Осмислюючи набутий педагогічний досвід, треба відзначити, що викладачам, котрі наважаться прийняти до себе на акторський курс студента із синдромом Дауна слід передусім поважно ставитись до такої людини, як зрештою і до будь-якої іншої особистості. Безперечно, потрібно також мати відчуття співчуття та милосердя. Також корисним буде здобуття викладачами додаткових знань, приміром, прослуховування курсу лекцій для підвищення кваліфікації з інклюзивної педагогіки, психології, антропології, навіть християнської етики. У розглянутому вище випадку викладачам стали у пригоді професіональні знання та навички з режисури, адже ця професія привчає до спостереження за людською поведінкою та вивчає сферу почуттів людини. Безперечно, знадобилися й власний педагогічний досвід та знання і практика спілкування у християнському середовищі.

Отже, з вище викладеного можна зробити такі висновки:

Законодавчі та державні органи в Україні останніми роками активізували роботу зі створення умов для інклюзивної освіти. Але при цьому переважно їхня діяльність спрямована на реформування шкільної освіти для дітей з особливими потребами, натомість у закладах вищої освіти значного прогресу не спостерігається;

Для осіб із синдромом Дауна здобуття акторської освіти та подальша робота за фахом стає фактором арт-терапії та сприяє соціалізації;

Професіональні актори з синдромом Дауна цілком реально можуть бути задіяними у театрально-кіно-мистецькому просторі України;

Досвід роботи викладачів зі студентом із синдромом Дауна довів, що такі індивіди цілком можуть оволодівати акторською професією в умовах колективного й індивідуалізованого навчання зі спеціальності актор драматичного театру. Даний досвід дав позитивні результати і його варто поширювати та вдосконалювати;

3 огляду на загалом індивідуалізований підхід у вузах до фахової підготовки акторів драматичного театру, немає потреби створювати якісь додаткові індивідуальні програми навчальних курсів для сту- дентів із синдромом Дауна. Для викладачів достатньо базових знань про особливості поведінки таких людей та вміння правильно налаштувати колектив студентів на прийняття у своє творче товариство колег з особливими потребами.

В цілому за останні роки в контексті реформування системи освіти почала стрімко розвиватись в Україні й інклюзивна освіта. Зокрема, в системі мистецької освіти у вищій школі відбуваються певні, хоч і незначні зміни: педагоги хочуть працювати 3 дітьми з особливими освітніми потребами, їх захоплює ця проблема, вони з ентузіазмом ставляться до експериментів залучення до навчання у колективі серед типових студентів також і осіб з особливими потребами, зокрема із синдромом Дауна;

Щодо мистецької інклюзивної освіти, то потрібно вивчати зарубіжний та вітчизняний досвід, щоб запроваджувати державні освітні програми. Слід зазначити, що загалом педагогам бракує спеціальних знань для того, щоб надавати якісні освітні послуги особам з особливими потребами, недостатня також нормативна-правова база, немає додаткового фінансування - нині реформою передбачено для кожного вчителя загальноосвітньої школи, який працює в інклюзивному класі, надбавку у розмірі 25 \% від заробітної платні;

Конче потрібно вдосконалювати нормативно-правові та фінансові підходи, адже не всі, як, приміром, згаданий вище студент Д. з КНУКіМ, мають змогу сплачувати за контрактом за своє навчання;

Також відчувається потреба у фаховій розробці методичних рекомендацій для викладачів, які займаються зі студентами з особливими освітніми потребами. Надалі необхідно продовжувати проводити інформаційну і роз'яснювальну роботу щодо популяризації інклюзивної освіти в Україні.

Даною науковою розвідкою ми лиш побіжно висвітлили досвід навчання осіб з особливими освітніми потребами за спеціальністю «Актор драматичного театру» та окреслили коло нагальних проблем, наявних у системі мистецької інклюзивної вищої освіти в Україні. Безперечно, такий аспект театральної педагогічної діяльності потребує подальшого всебічного вивчення проблеми різними фахівцями - викладачами вузів, практиками у галузі театру та кіно, медиками та психологами.

\section{Джерела та література}

1. Безгін, О., Миленька Г. Міжнародний фестиваль театральних шкіл (Пекін, 2009) // Науковий вісник Київського національного університету театру, кіно і телебачення імені I. К. Карпенка-Карого. Київ, 2010. Вип. 6. С. 341-352.

2. Бурлуцький, А. Засоби створення образності мовлення // Науковий вісник Київського національного університету 
театру, кіно і телебачення імені I. К. Карпенка-Карого. Київ, 2011. Вип. 7. С. 339-347.

3. Висоцький, Ю. Наближення до Мольєра: (Про деякі змістовні аспекти роботи над дипломною виставою на акторському курсі) // Науковий вісник Київського начіонального університету театру, кіно і телебачення імені I. К. Карпенка-Карого. Київ, 2009. Вип. 4-5. С. 450-469.

4. Висоцький, Ю. Приблемні питання методики виховання актора // Науковий вісник Київського національного університету театру, кіно і телебачення імені I. К. Карпенка-Карого. Київ, 2007. Вип. 1. С. 201-208.

5. Висоцький, Ю. Принципові питання практики і теорії акторського тренінгу // Науковий вісник Київського національного університету театру, кіно і телебачення імені I. К. Карпенка-Карого. Київ, 2008. Вип. 2-3. С. 210-226.

6. Закон України Про внесення змін до Закону України «Про освіту» щодо особливостей доступу осіб з особливими освітніми потребами до освітніх послуг від 23.05.2017 № 2053-VIII. [Електронний ресурс]. Режим доступу: http://zakon3. rada. gov. ua/laws/show/2053-19

7. Закон України Про освіту // Відомості Верховної Ради, 2017, № 38-39, С. 380. Режим доступу: http://zakon2. rada. gov. ua/laws/show/2145-19

8. Зима, В. Марина Порошенко: Вперше за 25 років Україна повернулася обличчям до дітей з особливими потребами / Василь Зима; [інтерв'ю з М. Порошенко]; 21 березня, 2017, 20:00. // Espreso. TV. Режим доступу: https://espreso. tv/article/2017/03/21/poroshenko

9. Кирик, Д. Зв'язок викладання філософії з профілем КНУ театру, кіно і телебачення імені І. К. Карпенка-Карого // Haуковий вісник Київського національного університету театру, кіно і телебачення імені I. К. Карпенка-Карого. Київ, 2010. Вип. 6. С. 352-363.

10. Кочарян, І. Навчальний процес у вищому закладі освіти: організаційний аспект. Зв'язок викладання філософії 3 профілем КНУ театру, кіно і телебачення імені І. К. Карпенка-Карого // Науковий вісник Київського національного університету театру, кіно і телебачення імені I. К. Карпенка-Карого. Київ, 2010. Вип. 6. С. 378-390.

11. Кочарян, I. Особливості фінансового менеджменту у вищих навчальних закладах // Науковий вісник Київського національного університету театру, кіно і телебачення імені I. К. Карпенка-Карого. Київ, 2009. Вип. 4-5. С. 483-493.

12. Кочарян, I. Проблеми вищої освіти України в сучасних умовах // Науковий вісник Київського начіонального університету театру, кіно і телебачення імені I. К. Карпенка-Карого. Київ, 2008. Вип. 2-3. С. 198-210.

13. Кочарян, І. Шляхи вдосконалення вищої мистецької освіти в контексті приєднання України до Болонського процесу // Науковий вісник Київського національного університету театру, кіно і телебачення імені I. К. Карпенка-Карого. Київ, 2007. Вип. 1. С. 188-195.

14. Максименко, Г. Реабілітація психофізичного апарату в пост-творчому періоді // Науковий вісник Київського національного університету театру, кіно і телебачення імені I. К. Карпенка-Карого. Київ, 2009. Вип. 4-5. С. 469-483.

15. Овчієва, Л. Адаптація першокурсників акторської спеціальності // Науковий вісник Київського національного університету театру, кіно і телебачення імені I. К. Карпенка-Карого. Київ, 2007. Вип. 1. С. 208-214.

16. Остропольський, Л. Про метод: «зазор і три «я»: взаємодія між особистістю актора та персонажем // Науковий вісник Київського національного університету театру, кіно і телебачення імені I. К. Карпенка-Карого. Київ, 2008. Вип. 2-3. С. 226-237.

17. Петелько, С. Удосконалення навчального процесу «Історія естрадного та циркового мистецтва» для студентів спеціалізації «Організація театральної справи» // Науковий вісник Київського національного університету театру, кіно і телебачення імені І. К. Карпенка-Карого. Київ, 2007. Вип. 1. С. 214-219.

18. Підлісна, Л. Від творчої уяви до словесної дієвості // Науковий вісник Київського начіонального університету театру, кіно і телебачення імені I. К. Карпенка-Карого. Київ, 2008. Вип. 2-3. С. 237-241.

19. Театр Простодушных. РФ: благотворительный проект. Режим доступа: http://театр простодушных. pф/?page id=35

20. Янчур, А. Самый солнечный театр. Репетиция единственного в Беларуси театра для молодежи с синдромом Дауна // TUT. BY. Режим доступа: https://news. tut. by/ society $/ 470019$. html? crnd $=26501$

\section{References}

1. Bezgin, O. \& Mylen'ka, H. (2010). International Festival of Theatre Schools (Beijing, 2009). Naukovyi visnyk Kyivskoho natsionalnoho universytetu teatru, kino i telebachennia imeni I. K. Karpenka-Karoho, 6, 341-352 [in Ukrainian].

2. Burlutskyi, A. (2011). Ways of imagery speech making. Naukovyi visnyk Kyivskoho natsionalnoho universytetu teatru, kino i telebachennia imeni I. K. Karpenka-Karoho, 7, 339-347 [in Ukrainian].

3. Vysots'kyi, Y. (2009). Bringing near Moliére (about some substantial aspects of Diploma performance on the actor's course). Naukovyi visnyk Kyivskoho natsionalnoho universytetu teatru, kino i telebachennia imeni I. K. KarpenkaKaroho, 4-5, 450-469 [in Ukrainian].

4. Vysots'kyi, Y. (2007). Principal questions of practice and theory of actor's training. Naukovyi visnyk Kyivskoho natsionalnoho universytetu teatru, kino i telebachennia imeni I. K. Karpenka-Karoho, 1, 201-208 [in Ukrainian].

5. Vysots'kyi, Y. (2008). Urgent problems of training actor's methods. Naukovyi visnyk Kyivskoho natsionalnoho universytetu teatru, kino i telebachennia imeni I. K. KarpenkaKaroho, 2-3, 210-226 [in Ukrainian].

6. Law of Ukraine On Amendments to Law of Ukraine «On Education» as regards Peculiarities of Access of Persons with Special Needs to Educational Services from 23.05.2017 № 2053-VIII. - URL: http://zakon3. rada. gov. ua/laws/ show/2053-19 [in Ukrainian].

7. Law of Ukraine On Education from 05.09.2017 № 214519.-URL: http://zakon2. rada. gov. ua/laws/show/2145-19 [in Ukrainian].

8. Zyma, V. (March 21, 2017). Marina Poroshenko: For the first time in 25 years Ukraine has turned to children with special needs. Espreso. TV. URL: https://espreso. tv/ article/2017/03/21/poroshenko [in Ukrainian].

9. Kyryk, D. (2010). Connection of philosophy teaching with the profile of Kyiv National I. K. Karpenko-Karyi University of theatre, cinema and television // Naukovyi visnyk Kyivskoho natsionalnoho universytetu teatru, kino i telebachennia imeni I. K. Karpenka-Karoho, 6, 352-363 [in Ukrainian].

10. Kocharyan, I. (2010). Studying process in a higher educational institution: organisation aspect // Naukovyi visnyk Kyivskoho natsionalnoho universytetu teatru, kino i telebachennia imeni I. K. Karpenka-Karoho, 6, 378-390 [in Ukrainian].

11. Kocharyan, I. (2009). Peculiarities of financial management in High Education Institutions // Naukovyi visnyk Kyivskoho natsionalnoho universytetu teatru, kino i telebachennia imeni I. K. Karpenka-Karoho, 4-5, 483-493 [in Ukrainian].

12. Kocharyan, I. (2008). The problems of higher education of Ukraine in the modern conditions // Naukovyi visnyk Kyivskoho natsionalnoho universytetu teatru, kino i telebachennia imeni I. K. Karpenka-Karoho, 2-3, 198-210 [in Ukrainian].

13. Kocharyan, I. (2007). The ways of improving higher art education in the context of Ukraine's joining to Bologna process // Naukovyi visnyk Kyivskoho natsionalnoho 
universytetu teatru, kino i telebachennia imeni I. K. KarpenkaKaroho, 1, 188-195 [in Ukrainian].

14. Maksymenko, H. (2009). Rehabilitation of an actor's psychophysical apparatus in post-creative period // Naukovyi visnyk Kyivskoho natsionalnoho universytetu teatru, kino i telebachennia imeni I. K. Karpenka-Karoho, 4-5, 469-483 [in Ukrainian].

15. Ovchiieva, L. (2007). The adaptation of first-year students to an actor specialization // Naukovyi visnyk Kyivskoho natsionalnoho universytetu teatru, kino i telebachennia imeni I. K. Karpenka-Karoho, 1, 208-214 [in Ukrainian].

16. Ostropol'skyi, L. (2008). About the method: «clearance and three „I"»: interaction between actor's personality and character // Naukovyi visnyk Kyivskoho natsionalnoho universytetu teatru, kino i telebachennia imeni I. K. KarpenkaKaroho, 2-3, 226-237 [in Ukrainian].
17. Petel'ko, S. (2007). Improving the academic course «The history of variety and circus art» for the students of the specialization «The theatrical work management» // Naukovyi visnyk Kyivskoho natsionalnoho universytetu teatru, kino i telebachennia imeni I. K. Karpenka-Karoho, 1, 214-219 [in Ukrainian].

18. Pidlisna, L. (2008). From creative imagination to the verbal activity // Naukovyi visnyk Kyivskoho natsionalnoho universytetu teatru, kino i telebachennia imeni I. K. KarpenkaKaroho, 2-3, 237-241 [in Ukrainian].

19. Theater of Simple-minded: charity project. URL: http://театр простодушных. pф/?page_id=35 [in Russian].

20. Yanchur, A. (October 29, 2015). The most sunny theater. Rehearsal of the only theater in Belarus for young people with Down syndrome. TUT. BY. URL: https://news. tut. by/ society/470019. html?crnd=26501 [in Russian]. 